UDC 811.111

DOI https://doi.org/10.32782/tps2663-4880/2019.10-1.23

\title{
ON SOME METHODS OF TEACHING READING TECHNIQUES IN FOREIGN LANGUAGES
}

\section{ПРО ДЕЯКІ МЕТОДИ ТЕХНІКИ ВИКЛАДАННЯ ЧИТАННЯ ІНОЗЕМНИМИ МОВАМИ}

\author{
Sorokina M.Ye. \\ orcid.org/0000-0001-6487-1751 \\ Senior Lecturer at the Department of Translation \\ Pryazovskyi State Technical University \\ Rud A.H. \\ orcid.org/0000-0001-8105-4630 \\ Senior Lecturer at the Department of Translation \\ Pryazovskyi State Technical University
}

Nowadays there exists plenty of opportunity to learn English and other foreign languages in active and creative way and to learn to use a foreign language to communicate with others and to search information that is needed. At the very first stage of learning a foreign language any pupil or student realizes that a language code exists. And it might be the first challenge both for a student and a teacher. People have different abilities and recourses, and ways of learning vary from person to person. All language teachers are familiar with this problem, and that is the reason for writing the given article just to suggest some approaches and methods of teaching reading techniques that might be helpful for teachers of foreign languages. The first challenge that a new learner comes across is the graphical presentation of letters that do not exist in a mother tongue. The second one is different transcription symbols. And the last one is the process of making sounds (training of unfamiliar articulation of foreign and strange sounds that can be time consuming). Here in the article are analyzed various methods of teaching reading techniques. Considered are the main operations lying in the basis of formation of reading techniques, as well as the classification of types of reading. Suggested is correlation of qualitative and quantitative detection of exercises aiming to form reading mechanisms. Theoretical issues are illustrated with examples. Also given were the parameters of evaluation. It is shown that the process side plays an important part in teaching techniques as its mastering ensures the content and sense side. Teaching is to be accompanied with active individual work, aimed at mastering complicated skills at learning foreign languages. Also shown is the role of reading for mastering various lexical pronunciation and grammar skills. It also helps to acquire speaking and listening abilities. Attention is given to mental processes and mechanisms that define reading as a cognitive process. Also is highlighted the necessity of systematization of reading exercises used according to their aim to form reading mechanisms and according to the stages of study.

Key words: teaching reading technique, reading as a type of language activity, text requirements, working methods, reading comprehension control.

Нині є безліч можливостей активно і творчо вивчати англійську та інші іноземні мови, а також навчитися використовувати іноземну мову для спілкування й пошуку необхідної інформації. На початковій стадії вивчення іноземної мови будь-який учень дізнається про те, що існує мовний код. Це може стати першою завадою як для студента, так і для викладача. Слід враховувати, що люди мають різні здібності та ресурси. Викладачам знайома ця проблема, котра визначила і мету статті - запропонувати деякі підходи та методи навчання техніки читання іноземною мовою (зокрема англійською), які можуть стати в нагоді молодим викладачам іноземних мов. Перша складність, із якою стикається початківець, що вивчає мову, - це графрічна презентація букв, яких немає в рідній мові. Друга - це різні символи транскрипції та правила читання. Й остання - це процес оволодіння вимовою звуків (тренування артикуляції іноземних і незвичних звуків може займати багато часу). У цій статті проаналізовано різні методи навчання техніки читання. Розглянуто головні операції, що лежать в основі формування техніки читання, а також класифікацію типів читання. Запропоновано баланс між якістю та кількістю вправ, спрямованих на фоормування механізмів читання. Теоретичні проблеми проілюстровано прикладами. У статті представлено параметри оцінювання та продемонстровано, що навчання повинне супроводжуватися активною індивідуальною роботою, спрямованою на покращення складних навичок під час вивчення іноземної мови. Також показано роль читання для вдосконалення лексичних і граматичних навичок, вимови, що допомагає покращувати й розвивати здатність говорити та чути. У статті увагу було звернено на деякі ментальні процеси й механізми, які визначають читання як пізнавальний процес. Підкреслено необхідність систематизації вправ, котрі використовуються відповідно до їх мети, а саме: формування механізмів читання на різних стадіях навчання.

Ключові слова: техніка читання, читання як різновид мовної активності, вимоги до текстового матеріалу, методи роботи, контроль розуміння прочитаного.

Formulation of the problem. Traditionally methods of teaching foreign languages (hereinafter: FL) imply formation of language and speech skills. If we are to speak about reading, then an ability to apply various techniques for extracting the required text information and their adequate application, depend- 
ing upon the task can be mentioned. Still, it is certain that reading technique is the basis of all such skills. Inability to adequately develop it or when it is not automatic enough inevitably leads to the situation when all reading technologies and method are at stake. It is understood that skills are primary in their nature while abilities are of secondary, so, it is evident that at the initial stage of teaching how to read in a foreign language the main goal could be formation of reading technique, i.e. "procedural plan".

Presenting main material. Reading technique is students' ability to unite the studied material into sense groups (syntagmas) by sound and letter correlations and develop them with appropriate intonation.

The following operations lie in the basis of formation of reading technique:

- correlation of a visual / graphic image of a reading unit with its auditory, speaking and visual image;

- correlation of auditory, speaking and visual images of speaking units with their meanings.

Teacher's task at formation of reading technique is:

- to leave out as early as possible an intermediate stage of reading uttering by establishing a direct correlation between the graphic image of speech units and their meanings;

- to steadily increase a unit of comprehended text until it is equal to syntagma by the end of the first year of study;

- to develop standard reading with observation of specified rate, stress standards, pause formation and intonation.

At the initial stage formation of reading technique is mainly a tutorial means. The principle of verbal advance is one of the key methodical principles, it means that acquaintance with words visual patterns is to take place after their auditory and motor patterns. The work at reading technique should commence with formation of students' grapheme-phoneme correlations.

The following difficulties exist on the way of teaching grapheme-phoneme correlations:

- existence of different correlation systems in mother tongue and foreign languages (external language interference);

- difference between graphic and sound systems of a foreign language (internal language).

- These difficulties are caused by the following main reasons:

1. Alphabet difficulties. Three groups of letters may be distinguished:

- letters fully coinciding with letters in the mother tongue (ABCOPKTHM);

- letters with only partial coincidence (YUD);

- completely different letters (QZFWJ);
- coincidence in letters can be a source of additional difficulties, as they may render different sounds;

- head letters may coincide while small letters may not $(\mathrm{T}-\mathrm{t})$.

Mastering Latin alphabet may sufficiently be accompanied with interfering influence of the mother tongue in the domain of graphics and phonation.

2. Existence of other methods of sounds rendering (not typical for Russian and Ukrainian):

- application of two letters for just 1 sound (th, sh, ng);

- dependence of vowels pronunciation upon the types of their position in stressed syllables;

- frequent lack of coincidence of the number of phonetic and spelling syllables in a word [teibl];

- no clear connection between sound and letter, the same letter or a combination of letters are often used for designation of different sounds (c, g, th, [o:] - or, aw, all).

- -As a rule an analytical-synthetic method of teaching reading technique is used at schools. Pupils are taught some reading rules (regularities of letters-sound correlations), word analysis is used for practical mastering, the word being decomposed into syllables with its subsequent automatic perception. However, in English not all regularities could be summarized into the rules available for learners. In this case, memorization could be reached by multiple repetition or reading.

At the initial stage frequently met words are learnt, which are irregularly read: (ha[ei]ve, ma[ei] ny, g[dj]irl, pu[A]t, o[эu]ne).

There exists another method of teaching reading technique - "key words method", in which key words are accompanied with colour signals, indicating sufficient signs of recognition of similar words by groups, promoting memorization of a graphical pattern of words of a particular type (high, light, night, sight, fight).

The following reading methods may be distinguished:

- sound reading;

- syllable reading;

- reading of whole words.

The latter two methods are typical to English.

The system of reading skills formation:

1. At the beginning of studies children learn consonants and the sounds they may contain. The letters are presented not in the alphabetic sequence, according to the frequency of their appearance in speech patterns, that children master.

2. Having learnt all consonants and enriched their vocabulary and speech repertoire by means of several communicative situations pupils start to 
read vowels in different words. It is important that reading should be based here on certain speaking skills. Children read and write what they talk about. Here a secondary mastering of speech patterns takes place and speech skills are transferred to formation of certain compensatory skills at reading. In this case children read actual words while transcription signs just help establish certain correlations between graphical and sound patterns of different words. An ability to read a word by its transcription signs is very important, as it ensures pupil's independence and guarantees success in his / her individual work. Though in our real life we never read anything written in transcription symbols. Simultaneously with reading of separate words the work, aimed at increasing the unit of comprehended text begins. Pupils read words and word combinations and then sentences, containing them or mini-texts, intended for training. Such important components of reading technique, like rate, intonation, stress, pauses and the like are formed at that. It's difficult to overestimate the role of such exercises like individual or in chorus repetition of words in class or text.

There exist the following parameters of evaluation of reading technique:

1) reading rate (the number of words per minute);

2) observation of stress regularities (sense, logical; an ability not to put stress on auxiliary words);

3) observation of the rules of pause making;

4) application of correct intonation patterns;

5) comprehension of the material read.

All parameters are equally important and determined the aggregate mark.

At the intermediate and senior teaching stages reading technique is corrected and perfected. With the objective of perfection of reading technique it is desirable to do exercises at class, specified for developing silent cursory reading, because pupils cannot control their own rate or accelerate it when they are engaged in individual reading. Loud reading can be good phonetic exercising, promoting, in case of its good organization development of speech skills and abilities. One or two text passages should be used for this purpose, a text part should be carefully drilled with pupils, phonetic marking being used. A diagram of teacher's and pupils' when working with texts intended for reading.

Development of a mechanism for loud reading with direct reading comprehension:

1. Oral advance. Learning lexical and grammar material in oral speech exercises.

2. Teacher's analysis of the text with determination of graphemes, which can may cause difficulties for pupils.
3. Communicative orientation at reading and direct comprehension of the material read by pupils.

4. Doing exercises for developing the skill of quick distinguishing of graphic patterns of letters. For example:

- read the letter;

- find a capital letter, a small letter ... among several ones;

- make up words from the following letters ...;

- name the words beginning with letter ...;

- show the letter corresponding to the sound etc.

Finding in a text words, word combinations with given graphemes, pupils have to pronounce them. For example:

- pick out the words, that are read according to / not according to / the rule;

- read similar words;

- pick up the words with a particular grapheme;

- make up words, by writing the missing letters;

- look at the following words and find the difference in them;

- reading words, by a key word end the like.

Listening to a text model and making by the pupils phonetic detachment of the text with control of its comprehension.

Repeated listening to the text and uttering speech patterns in pauses with a specified task.

Revelation and correction of mistakes, made by the pupils while reading the text on the basis of imitation and the rules.

Syntagmatic text reading, following the speaker / the teacher / supported by the text.

Individual reading and reading in chorus with simultaneous execution of a communicative task, aimed at understanding of the material read.

Control loud reading of the text by separate pupils.

Summing up and giving marks to the pupils for their reading technique.

Reading as a type of speech activity is a process of perception and energetic processing of information that is graphically coded in accordance with the system of one or another language.

Two plans may be distinguished in reading, like in other type of activity:

The contents (components of the contents i.e. what is the text about);

The process (elements of the activity, i.e. how it should be read and pronounced).

It should be noted that the first plan always occupies the main part. The content of an activity primarily means its task -i.e. the result at reaching of which it is aimed. For reading this task is revelation of sense connections-understanding of a speech product, represented in a written form (the text). 
You may address to a book, pursuing different objectives: sometimes you may need to know just what it is about in other cases you may need to know its author's ideas etc., so the desired result is always different. The character of comprehension (the degree of its completeness, its depth and precision) of the read material depends on the reading objective. It determines, in its turn, in what way it is going to be read: slowly or quickly, carefully reading each work or passing certain sections of the text, re-reading some text passages or looking through pages in a "diagonal" way. In other words the process of reading is not anything stable or constant it changes, under the influence of the reading task: a reader wants to achieve the goal in the easiest and most economic way, just like in other human activity. The more experienced the reader is the better he / she fulfills his / her task. His / her reading possesses a flexible character. Flexibility is a distinguishing feature of an experienced reader.

A mature reader is a person, who is capable of realizing a particular type of speech activity, due to his / her ability to select every time the reading type, adequate to the task he / she is facing, it allowing him finding a quick and correct way of solving it, due to complete automation of his / her technique skills. Reading is a task and means of teaching foreign languages.

Mastering reading skills in F.L. is one of the practical tasks of this subject at secondary schools, i.e. pupils are supposed to master reading as a means of reaching information. Reading has also educational and pedagogical objectives. Reading is a good way to execute the cognitive language function and a careful selection of texts gives an opportunity to use the information that they contain for extension of pupils' outlook. It also may have some pedagogical tasks. Reading helps develop the skills of language observation and the pupils are taught to pay greater attention to language expression of their thoughts. Reading is also a means of quicker mastering language and speech material of the language studied.

Reading has some links with psychic processes:

- memory;

- thinking (comparisons, generalizations, analyses, synthesis, abstractions etc.);

- internal repetition;

- sense anticipation (anticipation at the levels of words, sentences, sense anticipation).

Reading possesses the following psycho-physiological mechanisms:

- perception;

- finding sound-letters correlations;

- anticipation;
- internal repetition;

- understanding and comprehension;

- detachment of sense landmarks.

Visual, speech motor and hearing analyzers are used in reading.

Like other types of speech activities it has three stages:

- motivational-impulsive (leading to the necessity to read);

- analytical-synthetic (mechanisms);

- executive (execution of the task set).

Nowadays there is no shortage of texts. The problem is how to select convenient tuition materials. To do it, it is necessary to determine the contemporary authentic texts. In this work we will restrict ourselves to most important ones.

Many scholars stick to the opinion that the vocabulary of pupils at the initial teaching stage does not allow to create interesting texts, having a lot of cognitive materials. There the text represent but a set of logically connected sentences. Still, we firmly believe that we practically can't do without them. That is why it's important to stuff theses texts with appropriate communicative tasks, to be done when working at them. It is desirable that they should be connected with the sense part of the material read, making a pupil think, revealing his / her personality and applying his / her life experience.

From the very beginning of teaching reading skills it is vital to cultivate certain culture of reading, i.e. teach to begin working with a text, what is to be done next and in what way such work is to be ended.

Silent reading is a principle means of acquiring information. It may be described as application of the developed pronouncing, lexical and grammar skills for getting some information from a text. It is highly advisable, whenever it is possible, to teach how to work with a text, even at initial tuition stages to teach how to read the text title thoughtfully and anticipate what will it be about. They won't be always be able to do it judging by the text title only, so, in this case, their attention should be paid to the first passage of the text, thus teaching them to be able to extract the main ideas of the material they are reading. Next important ability is an ability to reduce text, i.e. an ability to render the essence of the text, using limited number of sentences. Finally, there comes an ability to interpret the digested material. These abilities can naturally be started the initial stages. If pupils manage to master reading, practically as a type of speech activity, i.e. are able to find out the required information it will help solve educational, pedagogical and cognitive tasks. Silent reading is checked after text tasks, 
which allow revealing of correct comprehension of the read material. For example, they may answer questions, find in the text and read aloud answer, find in the text and read aloud 2-3 sentences, in which there is a description ... (what is described is indicated), select sentences from the text, in which ... is described, select $4-5$ sentences, that render the main idea of the text etc.
Conclusions. The process side plays an important part in teaching techniques as its mastering ensures the content and sense side. Teaching is to be accompanied with active individual work, aimed at mastering complicated skills at learning FL. Also shown was the role of reading for mastering various lexical pronunciation and grammar skills. It also helps to acquire speaking and listening abilities.

\title{
REFERENCES:
}

1. Дьюи Д. Психология и педагогика мышления / пер. с англ. Н.М. Никольской. Москва : Совершенство, 1997. 208 c.

2. Зимняя И.А. Педагогическая психология. Ростов-на-Дону : Феникс, 1997. 480 с.

3. Кларин М.В. Инновации в мировой педагогике: обучение на основе исследования, игры и дискуссии. (Анализ зарубежного опыта). Рига : НПЦ «Эксперимент», 1995. 176 с.

4. Gerngross G., Puchta H. Teaching foreign languages in primary schools. Іноземні мови. 2001. № 4. С. 48-50.

5. Glazyrina E.D., Efremova J.N., Nguyen T. organization of educational work with foreign listeners of the preparatory department. Modern problems of science and education. 2014. № 3. URL: http://www.science-education. $\mathrm{ru} / \mathrm{ru} /$ article/view?id=12887.

6. Sorokina M., Rude A. Application of interactive Internet tools for developing student's professional communication skills at teaching English. Міжнародний науковий журнал «lнтернаука». 2018. № 10 (50). Т. 1. C. 47-50.

7. Votyakova M.A., Sorokina M.E. Studying Languages with application of mobile applications. United-Journal. № 15. C. 13-14.

\section{ФРАЗЕЛОГІЧНА ОКАЗІОНАЛЬНІСТЬ ЯК ЗАСІБ СТВОРЕННЯ ЕМФАЗИ В ХУДОЖНЬОМУ ДИСКУРСІ (НА МАТЕРІАЛІ АНГЛІЙСЬКОЇ МОВИ)}

\section{PHRASEOLOGICAL OCCASIONALITY AS A MEANS OF CREATING EMPHASIS IN FICTIONAL DISCOURSE (ON THE MATERIAL OF ENGLISH)}

\author{
Татаровська O.В. \\ orcid.org/0000-0002-0703-3054 \\ кандидат філологічних наук, дочент, \\ дочент кафедри англійської філологї̈ \\ Львівського національного університету імені Івана Франка
}

\footnotetext{
У статті на матеріалі окремих прозових творів англійських письменників з'ясовано прагматичну ефективність художнього тексту, що переважно будується на комплексі стилістичних прийомів, які автор використовує для реалізації своїх емоційних і мисленнєвих інтенцій. Серед стилістичних прийомів емфаза займає центральне місце.

Емфаза як стилістичний прийом створюється одиницями різних рівнів мови, охоплюючи також лексико-фразеологічний. Передусім фрразеологічні одиниці завдяки притаманній їм образності, семантичній двоплановості та гнучкості більше, ніж інші знаки, схильні до стилістичного фрнкціонування в дискурсі та часто застосовуються для створення емфази. Цьому, зокрема, сприяє той факт, що всі без винятку фразеологічні одиниці мають експресивність, ступінь якої визначається особливостями фразеологічної конотації, а саме набором номінативно закріплених ознак, таких як оціночність, емотивність та інтенсивність.

Таким чином, номінативна інтенсивність та емфаза, або стилістична інтенсивність, протиставляються як мовні та мовленнєві явища відповідно. Як об'єднуючу ланку можемо розглядати явище інтенсифікації - динамічний процес, внаслідок якого номінативно закріплені ознаки денотата набувають додаткової яскравості, акцентуються, а одиниця, котра використовується, набуває нового заряду експресивності.

Інтенсифікація завжди супроводжує оказінальну номінацію, оскільки оказіоналізм привносить у контекст елемент новизни, що вже саме по собі привертає увагу читача і, зрозуміло, сприяє більшій експресивності тексту. Сила стилістичного ефекту, яка створюється, безпосередньо залежить від складності перетворення, особливо коли воно скеровується на оновлення фразеологічної образності. Як доводять проаналізовані приклади, створення на базі фразеологічні одиниці яскравого нестандартного образу значно підвищує її можливості як виразного засобу.

Ключові слова: емфаза, інтенсивність, емотивність, оціночність, фрразеологічна одиниця (ФО).
} 